\title{
Irrigation water management through using polyethylene mulch material
}

\author{
Md. Jafar Ullah, Sumya Binta Belayet Linu, M. M. Islam, Kaniz Fatima and M. S. Mahmud \\ Sher-e-Bangla Agricultural University, Dhaka, Bangladesh
}

\author{
Correspondence: Md. Jafar Ullah, Department of Agronomy, Sher-e-Bangla Agricultural University, Dhaka, Bangladesh, \\ Email jafarullahsau@gmail.com
}

Received: April 15, 2019 | Published: May 23, 2019

Copyright@ 2019 Ullah et al. This is an open access article distributed under the terms of the Creative Commons Attribution License, which permits unrestricted use, distribution, and reproduction in any medium, provided the original author and source are credited.

\begin{abstract}
An experiment was conducted at Sher-e-Bangla Agricultural University farm to study the effect of irrigation frequencies and polythene mulching on the growth and yield of white maize (PSC-121) during winter 2015-16. Polythene mulching had two treatments; without polythene ( $\left.\mathrm{P}_{0}\right)$ and $\mathrm{P}$ (Polythene). Four irrigation frequencies constituted the irrigation treatment $\left(I_{1}=\right.$ One irrigation at 15 DAS, $I_{2}=$ Two irrigations at 15 and 30 DAS, $I_{3}=$ Three irrigations at 15,30 and 60 DAS, $I_{4}=$ Four irrigations at 15, 30, 60 and 90 DAS) along with control. Polythene was applied between two adjacent rows of maize following each irrigation. The trial was conducted following split-plot design assigning polythene in the main plot and irrigations in the subplot. Results showed that polythene application showed $35 \%$ increase in yield over without polythene $(6.970 \mathrm{t} / \mathrm{ha})$. Likewise irrigation treatments $\mathrm{I}_{3}$ and $\mathrm{I}_{4}$ had statistically similar seed yields $(10.540$ and 10.610 $\mathrm{t} /$ ha) which were significantly higher than others irrigation treatments. The combination treatments $\mathrm{PI}_{3}$ and $\mathrm{PI}_{4}$ showed significantly higher seed yields $(12.72$ and $12.810 \mathrm{t} /$ ha respectively) than other treatment combinations which may be attributed to the increased dry matter, leaf area index, number of grains per cob and 100 -seed weight as were shown by these two treatments. However, the seed yields obtained from these two treatment combinations were at par. So, it may be concluded that the using polythene along with the application of three irrigations at 30,60 and 90 DAS may be followed to grow white maize.
\end{abstract}

\section{Introduction}

Maize is one of the most important food grains in the world as well as in developing countries. It is the third most important cereal crop in the world after wheat and rice. It is high yielder in comparison to rice and wheat occupying first position among the cereals in terms of yield covering 335 thousand hectares with total per annum production of 2448 thousand $\mathrm{m}$ ton/year. The productivity of maize is $5.36 \mathrm{t} /$ ha and on the contrary that of wheat and rice are 2.21 and $2.15 \mathrm{t} /$ ha respectively. ${ }^{1}$ Two types of maize are cultivated around the world, yellow maize and white maize. White maize, although is biologically and genetically very similar to yellow maize, it lacks in carotene pigments in its kernel, but worldwide it has more preference in the preparation of food items as compared to the yellow maize. ${ }^{2,3}$

White and yellow maize occupy approximately equal areas when maize grown in temperate zones is excluded. In Bangladesh maize is mostly used as feed try of which a substantial portion is imported. ${ }^{1}$ In Bangladesh although the annual rainfall is plenty $(2000-2500 \mathrm{~mm})$ it is not uniform and in the winter (September to February) the rainfall is not enough as per requirement of the corps (Figures 1 and 2) $)^{1,4}$ wherein the maize is normally grown for grain production purpose. So, for getting good production, maize field needs to be irrigated. The level of irrigation for maize production has been recommended by BARI ${ }^{5}$ but that is neither location specific nor varietal specific as both the location and variety determines frequency of the irrigation greatly. ${ }^{6}$ Maize has been reported in the literature as having high irrigation requirements. ${ }^{78} \mathrm{~A}$ great challenge for the agricultural sector is to produce more food from less water, particularly in arid and semiarid regions which suffer from water scarcity.
Irrigation frequency that results in either excessive or inadequate water supply can have a negative impact on final grain yield. For instance, very high irrigation frequency, once or more every day, might provide desirable conditions for water uptake by roots, but it will also lessen irrigation efficiency, increase energy and labor cost, and leach water and nutrients below the root zone. ${ }^{9,10}$ Very low irrigation frequency, on the other hand, may cause water stress between irrigations, because the duration of water application is much shorter than the time over which plants take up water. Low irrigation frequency may result in substantial percolation below the root zone during irrigation because the amount of water applied at each irrigation may be higher than the soil-water storage capacity. Therefore, a proper irrigation frequency is one which minimizes the amount of water leaching from the root zone, provides at lowest requirements of water to a portion of the root zone of each plant and maintains a high soil matric potential in the rhizosphere to reduce plant water stress between irrigations.

With a rapidly growing population, the pressure on limited fresh water resources increases. The agricultural sector faces the challenge to produce more food with less water by increasing Crop Water Productivity. ${ }^{11}$ On above discussed considerations, there must be an adjustment of polythene mulch and the frequency of irrigation.

By the year 2050, it is forecasted that there will be an annual global water shortage of 640 billion cubic meters. ${ }^{12}$ Therefore, water shortage events have to be given importance in both the scientific and political agendas as the irrigation sector is the largest consumptive user of water that accounts for $71 \%$ of the freshwater use across the world..$^{13}$

Mulching is a desirable management practice which regulates farm 
environment by reducing leaching and evapotranspiration and reduces nutrient loss due to run off. ${ }^{14}$ Mulches may be either organic or inorganic (polythene). The most frequently used organic materials include plant residues such as straw, hay, peanut hull and compost; wood products such as saw dust, wood chips/shavings and animal wastes. However, natural mulch materials are often not available in adequate quantities for commercial operations or must be hauled to the place of use. Excessive use of unsorted organic wastes as mulches may lead to changes in soil physical and chemical characteristics which may distort the inter-relationships among biophysical and chemical soil functions. It may also lead to loading of nitrates and heavy metals in the soil. ${ }^{15}$

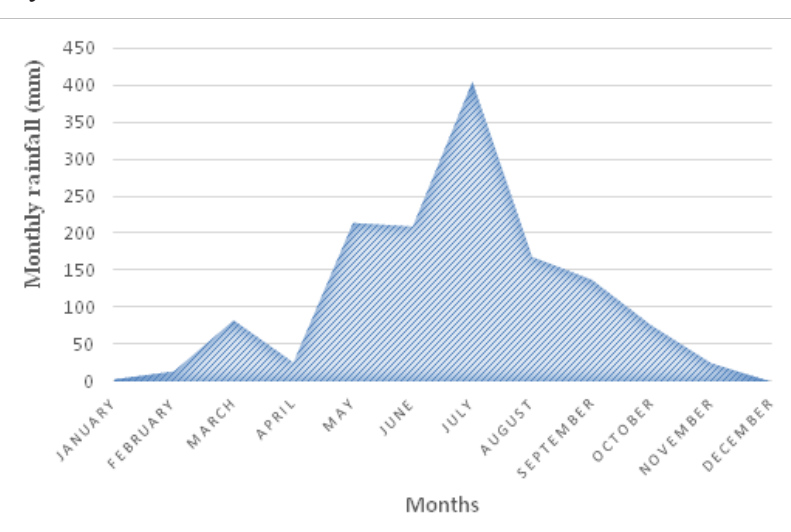

Figure I Monthly rainfall during $2016(\mathrm{~mm})$ at Dhaka in Bangladesh.'

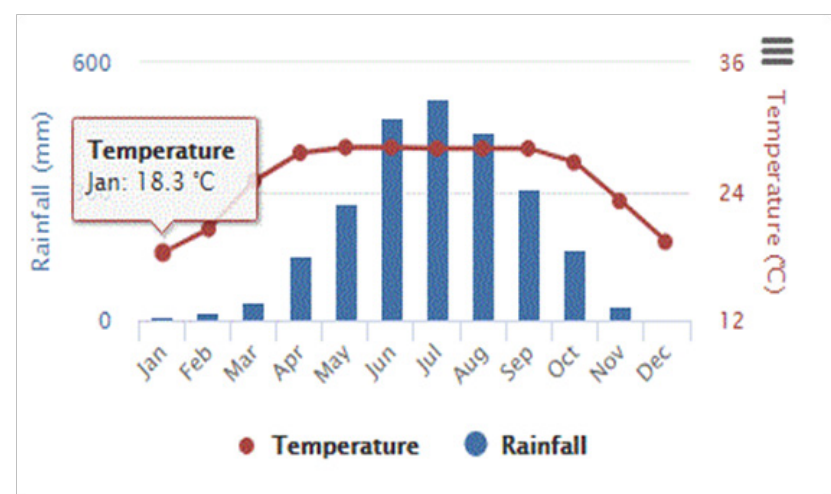

Figure 2 Monthly rainfall and temperature during 200I-20I5 (mm) at Dhaka in Bangladesh. ${ }^{4}$

Nowadays, polythene mulch cultivation has gradually become a great break-through in agricultural production. ${ }^{16}$ Katan et al. ${ }^{17}$ identified another sort of usefulness using plastic film mulch to achieve high soil temperature which helps to destroy soil pathogenic weeds nematodes. Moreover, the polythene mulch is less costly, easily available and may also be recycled.

Keeping all points in minds mentioned above, the research work was initiated to assess the impact of polythene mulch on white maize growth and productivity under varying irrigation frequencies on white maize growth and productivity.

\section{Materials and Methods}

An experiment was carried out at the Agronomy Field of Sher-eBangla Agricultural University, Dhaka-1207 during November 27, 2015 to May 2016 to evaluate the effect of polythene mulching and irrigation application at varying growth stages to examine combine effects on growth and yield of white maize. The experiment comprised two factors; polythene mulching $\left(\mathrm{P}_{0}=\right.$ no polythene mulching, $\mathrm{P}=$ polythene mulching $)$ and irrigation frequency $\left(\mathrm{I}_{0}=\right.$ no irrigation, $\mathrm{I}_{1}=$ one irrigation at 15 DAS, $I_{2}=$ two irrigations at 15 and 30 DAS, $I_{3}=$ three irrigations at 15,30 and $60 \mathrm{DAS}, \mathrm{I}_{4}=$ four irrigations at 15,30 , 60 and $90 \mathrm{DAS})$. The plots imposed with $\mathrm{I}_{0}$ treatments, no irrigation was provided except in the case of severe drought stress only a life saving irrigation was given. All the individual plots were surrounded by ten inches high bunds so as to control the intruded irrigation water during irrigation time. All the irrigation treatments were implied in bed irrigation method; where irrigation water was supplied in the inter plot irrigation channels. During irrigation, a six inches sub channel was made at the channel side boundary bund so as to allow intrusion of irrigation water into the plot. The intrusion of irrigation in the individual plots was allowed for the enough time so that the soil get enough water to be saturated. After nearing saturation the six inches sub-channel was closed.

Before sowing the land was divided in to three blocks (replication), each blocks had ten plots and as such three blocks had thirty plots wherein ten treatment combinations were assigned $\left(\mathrm{P}_{0} \mathrm{I}_{0}, \mathrm{P}_{0} \mathrm{I}_{1}, \mathrm{P}_{0} \mathrm{I}_{2}, \mathrm{P}_{0} \mathrm{I}_{3}\right.$, $\mathrm{P}_{0} \mathrm{I}_{4}, \mathrm{PI}_{0}, \mathrm{PI}_{1}, \mathrm{PI}_{2}, \mathrm{PI}_{3}, \mathrm{PI}_{4}$ ) randomly. Between two adjacent block one meter space was kept fallow for preparing irrigation channel. From this fallow area soil was dug to make bunds around the individual plots to control irrigation water. The experiment was laid out in a split-plot design placing irrigation treatments in the main plot and mulching in the sub plot.

Sher-e-Bangla Agricultural University Farm is situated at $23^{\circ} 41^{\prime} \mathrm{N}$ latitude and $90^{\circ} 22^{\prime} \mathrm{E}$ longitude at a height of $8.6 \mathrm{~m}$ above the sea level belonging to the Agro-ecological Zone "AEZ-28" of Madhupur Tract. Winter season's temperature is generally low which tends to increase from February as the season proceeds towards summer. Rainfall remains almost nil during the period from November to February and scanty from February to March. There remains plenty of sunshine in winter provided there is no abnormal rainfall.

The soil of the experimental field was slightly acidic, with low N, K, $\mathrm{Mg}$. P, S and B. The land was harrowed four times and each time was followed by laddering. At final land preparation the soil was provided with N, P, K, S, Zn and B from urea, triple super sulphate, muriate of potash, gypsum, zinc sulphate and boric acid as per the recommended dose of BARI 2011. Urea was splitted at 30 and 45 days after sowing at equal rates just after irrigation when leaves were dried and there was no standing water on the soil surface.

Seeds were sown maintaining row to row distance of $60 \mathrm{~cm}$ and plant to plant distance within each row $25 \mathrm{~cm}$. Two seeds in each hill were sown, seeds germinated 4 days after sowing. The germinated weaker seedling was removed 15 days after emergence and weeding was done two times; 30 and 45 days after sowing. Irrigation was provided as per the treatments. The soil surface between the plant rows were covered by the polythenes as per treatments. Other agronomic operations were done following the recommended packages of BARI. ${ }^{5}$

Data were collected on plant height at different stages (30, 60, 90 days after sowing, DAS and at harvest) measuring from the soil surface to the tip of the uppermost leaf. Base circumference was measured five centimeter above the soil at 30 and 60 DAS. Dry matter was monitored at 30,60, 90 and at harvest by sampling five plants from each plot cutting the plants at the base above the soil surface, drying at 70 degree $\mathrm{C}$ in electric oven until the constant weight and finally 
average value was calculated. At these days the leaf area index was also measured taking data of the leaf length and width and then multiplied by a K-coefficient factor of 0.75 following Musa and Usman. ${ }^{18}$ The leaf area was then summed up and averaged for per plant. Leaf area index was then calculated using the formulae: Leaf area of each plant divided by the land area occupied by each plant. Data were also taken on the cob length (from base of the cob containing grain to the apex), cob circumference, number of rows per cob, number of grains and grain weight per cob selecting five plants at random at harvest. Seed yield/ha was determined harvesting plants from central three linear meter of each plot, threshing the grains from cob, drying in the sun at $12 \%$ moisture, weighted and then the weight was converted in to hectare. 100 seed weight was calculated counting 100 seeds randomly from the harvested sample. After separating the cobs, the harvested sample was dried in the sun up to $12 \%$ moisture, the straw weight was taken and then adjusted in to dry weight per hectare. Harvest index was calculated through dividing the seed weight by the biological yield (seed yield plus straw yield) and multiplied by 100 to express in terms of percentage.

Collected data were analyzed using Mstat-C to find out the statistical significance and the treatment means were compared by Least Significant Difference (LSD) technique at 5\% level of significance.

\section{Results and discussion}

Plant height of maize was found statistically significantly as affected by the application of polythene mulch increasing the plant height of maize (Table 1). The longest plant (37.92, 65.71, 170.3 and 173.3 $\mathrm{cm})$ was recorded with the polythene mulching $\left(\mathrm{P}_{1}\right)$ at all the growth stages of 30,60, 90 and at harvest stages respectively. Whereas, the shortest plant heights $(28.13,137.7$ and $142.0 \mathrm{~cm})$ were observed in $\mathrm{P}_{0}$ (control).

Table I Effect of polythene mulching on plant height of white maize

\begin{tabular}{lllll}
\hline \multirow{2}{*}{ Treatments } & \multicolumn{4}{l}{ Plant height $(\mathrm{cm})$} \\
& 30 DAS & $60 \mathrm{DAS}$ & 90DAS & At Harvest \\
\hline $\mathrm{P}_{0}$ & $28.13 \mathrm{~b}$ & $47.40 \mathrm{~b}$ & $137.7 \mathrm{~b}$ & $142.00 \mathrm{~b}$ \\
$\mathrm{P}$ & $37.92 \mathrm{a}$ & $65.71 \mathrm{a}$ & $170.3 \mathrm{a}$ & $173.3 \mathrm{a}$ \\
\hline LSD (0.05) & 4.308 & 7.8 & 7.49 & 9.38 \\
CV\% & 8.3 & 8.78 & 3.09 & 3.79 \\
\hline
\end{tabular}

Statistically significant variations were also observed in plant height except at 30 DAS by different irrigation timings (Table 2) having the longest plants $(41.41,71.62,183.6$ and $186.1 \mathrm{~cm})$ with $\mathrm{I}_{4}$ and the shortest plants $(33.83,44.77,122.7$ and $127.4 \mathrm{~cm})$ with $\mathrm{I}_{0}$ treatment at the respective growth stages. $\mathrm{I}_{3}$ treatment showed second highest plant height $(38.88,68.23,173.9$ and $181.1 \mathrm{~cm})$ which was very close to $\mathrm{I}_{4}$ treatment.

Excepting at 30 DAS, the interaction effect of polythene mulch and irrigation treatments showed significant differences (Figure 3) at 60, 90 DAS and at harvest. However, the effect was non-significant at 30 DAS. At all growth stages, the highest plant height $(46.93,78.91$, 196.6 and $200.8 \mathrm{~cm}$ ) was observed from the combination of $\mathrm{PI}_{4}$ treatment which was statistically similar with $\mathrm{PI}_{3}$ treatment at 60,90 DAS and harvesting stage. The lowest plant heights $(27.67,34.87$, 99.67 and $104.1 \mathrm{~cm}$ ) were observed in $\mathrm{P}_{0} \mathrm{I}_{0}$ treatment.

Base circumference is an important character in maize as it has an influence of lodging tendency of the plants when faces strong wind (storm) when the stem base is narrow. Significant difference was observed on the base circumference of maize at 60 DAS (Table 3). Among the mulching and control, polythene mulching showed the highest base circumference $(6.64 \mathrm{~cm}$ at $60 \mathrm{DAS})$ and the bare soil (no mulching) showed the lowest base circumference $(4.91 \mathrm{~cm}$ at 60 DAS). Probably mulching helped conserve the soil moisture and the plenty supply of soil moister intern helped the stem to increase the base circumference. At 90 DAS, significant difference was observed also on base circumference of maize. The highest base circumference $(8.71 \mathrm{~cm})$ was found on treatment $P$ and the lowest $(6.83 \mathrm{~cm})$ was on $\mathrm{P}_{0}$. This is similar to the findings of Duhr and Dubas ${ }^{19}$ who reported that mulched plants had enhanced growth and stem circumference in maize.

Table 2 Effect of irrigation frequency on plant height of white maize

\begin{tabular}{lllll}
\hline \multirow{5}{*}{ Treatments } & \multicolumn{4}{l}{ Plant height $(\mathrm{cm})$} \\
& $30 \mathrm{DAS}$ & $60 \mathrm{DAS}$ & $90 \mathrm{DAS}$ & $\begin{array}{l}\text { At } \\
\text { Harvest }\end{array}$ \\
\hline $\mathrm{I}_{0}$ & $25.63 \mathrm{c}$ & $44.77 \mathrm{~d}$ & $122.7 \mathrm{e}$ & $127.4 \mathrm{e}$ \\
$\mathrm{I}_{1}$ & $28.83 \mathrm{bc}$ & $45.33 \mathrm{~d}$ & $134.8 \mathrm{~d}$ & $137.0 \mathrm{~d}$ \\
$\mathrm{I}_{2}$ & $30.38 \mathrm{~b}$ & $52.84 \mathrm{c}$ & $154.9 \mathrm{c}$ & $156.8 \mathrm{c}$ \\
$\mathrm{I}_{3}$ & $38.88 \mathrm{a}$ & $68.23 \mathrm{~b}$ & $173.9 \mathrm{~b}$ & $181.0 \mathrm{~b}$ \\
$\mathrm{I}_{4}$ & $41.41 \mathrm{a}$ & $71.62 \mathrm{a}$ & $183.6 \mathrm{a}$ & $186.1 \mathrm{a}$ \\
\hline LSD $(0.05)$ & 3.93 & 2.59 & 5.49 & 4.71 \\
$\mathrm{CV} \%$ & 9.72 & 3.75 & 2.91 & 2.44 \\
\hline
\end{tabular}

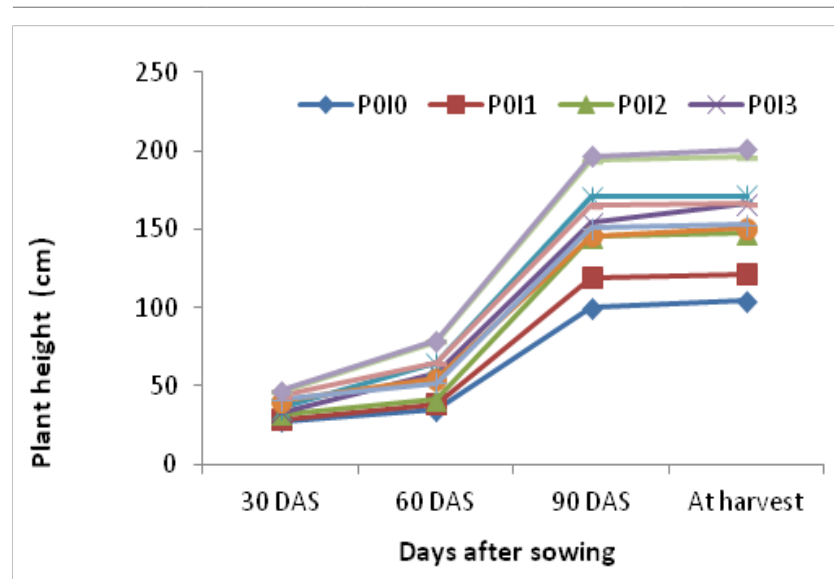

Figure 3 Interaction effect of polythene mulching and irrigation frequency on plant height of white maize

Irrigation frequency showed a significant variation on base circumference both at 60 and 90 DAS (Table 4). At 60 and 90 DAS, four frequent irrigation $\left(\mathrm{I}_{4}\right)$ showed the highest base circumference $(7.60$ and $9.355 \mathrm{~cm})$ although which was statistically similar with treatment $\mathrm{I}_{3}$. Whereas no irrigation treatment $\left(\mathrm{I}_{0}\right)$ showed the lowest base circumference $(3.817$ and $5.717 \mathrm{~cm})$. Pandey et al. ${ }^{20}$ stated that applying drought stress at various growth stages of corn generally reduced stem circumference and plant height. This study shows that the irrigation water application increases the growth and stem circumference of maize.

Interaction of polythene mulching and irrigation frequency showed significant variation in stem base circumference of white maize. The base circumference increased with the advances of growth period in respect of base circumference (Figure 4). At 60 DAS, the highest base 
circumference $(9.0 \mathrm{~cm})$ was observed in $\mathrm{PI}_{4}$ which was statistically similar with $\mathrm{PI}_{3}$

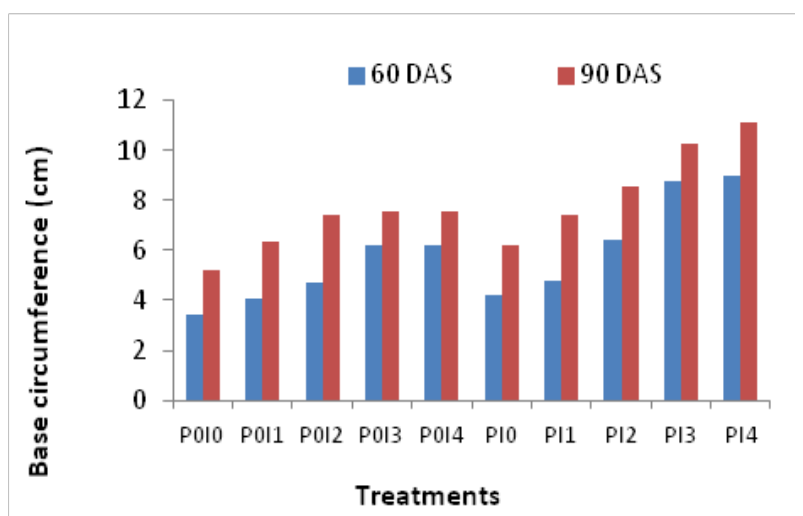

Figure 4 Interaction effect of polythene mulching and irrigation frequency on base circumference of white maize

$(3.40 \mathrm{~cm})$ was observed in $\mathrm{P}_{0} \mathrm{I}_{0}$. At 90 DAS, the highest base circumference $(11.13 \mathrm{~cm})$ was observed in $\mathrm{PI}_{4}$ which was statistically similar with $\mathrm{PI}_{3}$; whereas the lowest base circumference $(5.20 \mathrm{~cm})$ was observed in $\mathrm{P}_{0} \mathrm{I}_{0}$ which was statistically similar $\mathrm{PI}_{0}$. Kalaghatagi et al. ${ }^{21}$ reported that irrigation with black polythene mulch spread between the rows significantly increased the dry matter and fodder yield as well as stem circumference also.

Dry matter content plant $^{-1}$ of maize showed statistically significant variation due to application of polythene mulch at 60,90 DAS and at harvest stage (Table 5). At 30 DAS, the variation among the treatment was non-significant. the highest $(0.922 \mathrm{~g})$ dry matter content plant ${ }^{-1}$ was recorded from treatment $\mathrm{P}$ and the corresponding lowest $(0.744$ g) quantity of was found in treatment $\mathrm{P}_{0}$.

Table 3 Effect of polythene mulching on plant base circumference of white maize

\begin{tabular}{lll}
\hline \multirow{2}{*}{ Treatments } & \multicolumn{2}{l}{ Plant base circumference $(\mathrm{cm})$} \\
& 30 DAS & 60DAS \\
\hline $\mathrm{P}_{0}$ & $4.9 \mathrm{l} \mathrm{b}$ & $6.83 \mathrm{~b}$ \\
$\mathrm{P}$ & $6.64 \mathrm{a}$ & $8.7 \mathrm{I} \mathrm{a}$ \\
\hline LSD $(0.05)$ & 0.38 & 0.69 \\
CV\% & 4.14 & 5.62 \\
\hline
\end{tabular}

Table 4 Effect of irrigation frequency on plant base circumference of white maize

\begin{tabular}{lll}
\hline \multirow{2}{*}{ Treatments } & \multicolumn{2}{l}{ Plant base circumference $(\mathrm{cm})$} \\
& 30 DAS & $60 D A S$ \\
\hline $\mathrm{I}_{0}$ & $3.817 \mathrm{~d}$ & $5.717 \mathrm{~d}$ \\
$\mathrm{I}_{1}$ & $4.417 \mathrm{c}$ & $6.893 \mathrm{c}$ \\
$\mathrm{I}_{2}$ & $5.555 \mathrm{~b}$ & $7.983 \mathrm{~b}$ \\
$\mathrm{I}_{3}$ & $7.482 \mathrm{a}$ & $8.905 \mathrm{a}$ \\
$\mathrm{I}_{4}$ & $7.600 \mathrm{a}$ & $9.355 \mathrm{a}$ \\
\hline LSD $(0.05)$ & 0.36 & 0.82 \\
CV\% & 5.08 & 8.58 \\
\hline
\end{tabular}

Table 5 Effect of polythene mulching on dry matter content of white maize

\begin{tabular}{lllll}
\hline \multirow{2}{*}{ Treatments } & \multicolumn{4}{l}{ Dry weight (g/plant) } \\
& 30 DAS & 60DAS & 90DAS & $\begin{array}{l}\text { At } \\
\text { Harvest }\end{array}$ \\
\hline $\mathrm{P}_{0}$ & 0.744 & $14.62 \mathrm{~b}$ & $23.84 \mathrm{~b}$ & $63.70 \mathrm{~b}$ \\
$\mathrm{P}$ & 0.922 & $22.16 \mathrm{a}$ & $33.37 \mathrm{a}$ & $82.07 \mathrm{a}$ \\
\hline LSD $(0.05)$ & $\mathrm{NS}$ & 1.58 & 1.88 & 1.50 \\
$\mathrm{CV} \%$ & 22.75 & 5.13 & 2.45 & 1.34 \\
\hline
\end{tabular}

At 60 DAS, the highest $(22.16 \mathrm{~g})$ dry weight plant $^{-1}$ was found in $\mathrm{P}$ treatment. The lowest $(14.62 \mathrm{~g})$ dry weight plant ${ }^{-1}$ was found in $\mathrm{P}_{0}$ treatment. At $90 \mathrm{DAS}$, the highest $(33.37 \mathrm{~g})$ dry weight plant $^{-1}$ was found in $\mathrm{P}$ treatment. The lowest $(33.37 \mathrm{~g})$ dry weight plant ${ }^{-1}$ was found in $\mathrm{P}_{0}$ treatment. At harvesting stage, the highest (82.07 g) dry weight plant ${ }^{-1}$ was found in $\mathrm{P}$ treatment. The lowest $(63.7 \mathrm{~g})$ dry weight plant ${ }^{-1}$ was found in $\mathrm{P}_{0}$ treatment.

Consistent with the present study, it has been reported that total dry weight production increased with the application of mulching compared to the bare plots.

Dry matter content plant ${ }^{-1}$ of white maize showed significant variation due to different levels of irrigation frequency at 60,90 DAS and harvesting stages. However, it was not significant at 30 DAS (Table 6). At $30 \mathrm{DAS}$, the highest $(0.922 \mathrm{~g})$ dry weight plant $^{-1}$ was recorded from treatment $\mathrm{I}_{4}$ and the corresponding lowest dry weight $0.718 \mathrm{~g}$ which was found in treatment $\mathrm{P}_{0}$. At $60 \mathrm{DAS}$, the highest $(25.28 \mathrm{~g})$ dry weight plant ${ }^{-1}$ was found in $\mathrm{I}_{4}$ treatment which was statistically similar with $\mathrm{I}_{3}(24.84 \mathrm{~g})$. The lowest $(8.78 \mathrm{~g})$ dry weight plant ${ }^{-1}$ was found in $\mathrm{I}_{0}$ treatment. At $90 \mathrm{DAS}$, the highest $(37.40 \mathrm{~g})$ dry weight plant ${ }^{-1}$ was also found in $\mathrm{I}_{4}$ treatment which was statistically similar with $\mathrm{I}_{3}(36.70 \mathrm{~g})$. The lowest $(18.28 \mathrm{~g})$ dry weight plant ${ }^{-1}$ was found in $\mathrm{I}_{0}$ treatment. At harvesting stage, the highest $(91.80 \mathrm{~g})$ dry weight plant ${ }^{-1}$ was found in $\mathrm{I}_{4}$ treatment. The lowest dry weight plant ${ }^{-1}$ was found in $\mathrm{I}_{0}(50.33 \mathrm{~g})$ treatment.

Table 6 Effect of irrigation frequency on dry matter content of white maize

\begin{tabular}{lllll}
\hline \multirow{2}{*}{ Treatments } & \multicolumn{2}{l}{ Dry weight (g/plant) } & \\
& 30 DAS & 60DAS & 90DAS & At Harvest \\
\hline $\mathrm{I}_{0}$ & 0.718 & $8.78 \mathrm{~d}$ & $18.28 \mathrm{~d}$ & $50.33 \mathrm{e}$ \\
$\mathrm{I}_{1}$ & 0.768 & $13.83 \mathrm{c}$ & $23.33 \mathrm{c}$ & $60.23 \mathrm{~d}$ \\
$\mathrm{I}_{2}$ & $0.84 \mathrm{I}$ & $19.22 \mathrm{~b}$ & $27.33 \mathrm{~b}$ & $72.23 \mathrm{c}$ \\
$\mathrm{I}_{3}$ & 0.915 & $24.84 \mathrm{a}$ & $36.70 \mathrm{a}$ & $89.80 \mathrm{~b}$ \\
$\mathrm{I}_{4}$ & 0.922 & $25.28 \mathrm{a}$ & $37.40 \mathrm{a}$ & $91.80 \mathrm{a}$ \\
\hline LSD (0.05) & $\mathrm{NS}$ & 1.11 & 1.44 & 1.02 \\
CV\% & 14.63 & 4.94 & 4.10 & 1.14 \\
\hline
\end{tabular}

At 30 DAS, the highest $(1.024 \mathrm{~g})$ dry weight plant $^{-1}$ was found in $\mathrm{PI}_{4}$ treatment (Figure 5). The lowest $(0.637 \mathrm{~g})$ dry weight plant ${ }^{-1}$ was found in $\mathrm{P}_{0} \mathrm{I}_{0}$. At $60 \mathrm{DAS}$, the highest $(29.22 \mathrm{~g})$ dry weight plant ${ }^{-1}$ was found in $\mathrm{PI}_{4}$ treatment which was statistically similar with $\mathrm{PI}_{3}$. On the other hand the lowest $(6.78 \mathrm{~g})$ dry weight plant 1 was found in $\mathrm{P}_{0} \mathrm{I}_{0}$ treatment. At 90 DAS, the highest $(43.67 \mathrm{~g})$ dry weight plant ${ }^{-1}$ was found in $\mathrm{PI}_{4}$ treatment which was statistically similar with $\mathrm{PI}_{3}$ (43.33). The lowest $(14.78 \mathrm{~g})$ dry weight plant ${ }^{-1}$ was found in $\mathrm{P}_{0} \mathrm{I}_{0}$ treatment.

At harvesting stage, the highest dry weight plant ${ }^{-1}$ was found in $\mathrm{PI}_{4}$ treatment $(98.50 \mathrm{~g})$ which was statistically similar with $\mathrm{PI}_{3}(97.23$ g) treatment. The lowest $(39.90 \mathrm{~g})$ dry weight plant $^{-1}$ was found in 
$\mathrm{P}_{0} \mathrm{I}_{0}$. The finding of the present study is in consistent with that of Kalaghatagi et al., ${ }^{21}$ who reported that irrigation along with applying black polythene mulch in maize field spread between the adjacent rows significantly increased the dry matter at harvest. Maize variety exhibited significant difference on leaf area index (LAI) at 60 and 90 DAS and harvesting stage (Table 7). Among the polythene mulching and control treatment, polythene mulching $(\mathrm{P})$ showed the maximum leaf area index $(0.82,2.09,4.023$ and 3.665 at 30, 60, 90 DAS and harvesting stage) and control $\left(\mathrm{P}_{0}\right)$ showed the minimum leaf area $(0.58,1.68,3.094$ and 2.727 at $30,60,90$ DAS and harvesting stage). Kulkarni et al..$^{22}$ also reported that the number of LAI of maize increased under black polythene mulch as compared to paddy straw mulch and no mulch treatment.

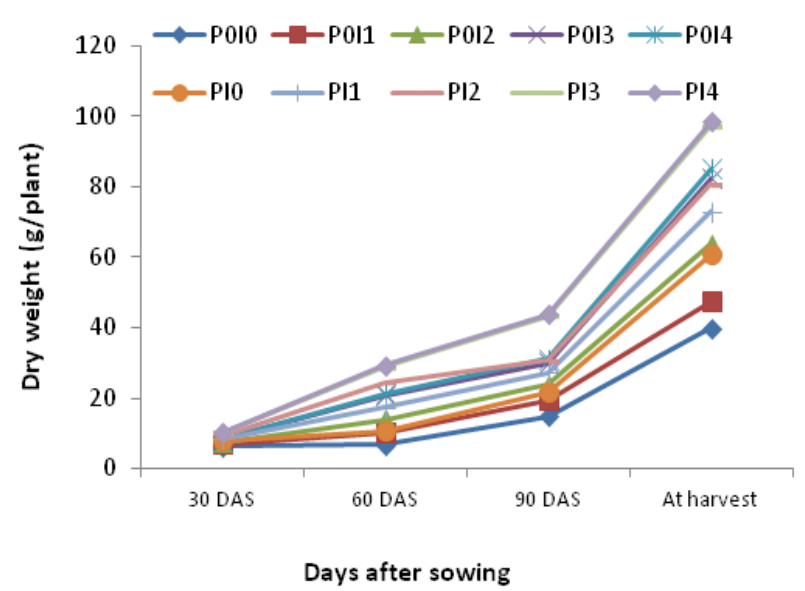

Figure 5 Interaction effect of polythene mulching and irrigation frequency on dry matter content of white maize

Irrigation frequency showed a significant variation on leaf area index at 60,90 DAS and harvesting stage and non-significant variation at 30 DAS (Table 8). At $30 \mathrm{DAS}, \mathrm{I}_{4}$ showed the maximum leaf area index $(0.81)$ and $\mathrm{I}_{0}$ showed the lowest leaf area index $(0.57)$; whereas at 60 , 90 DAS and harvesting stage, the highest leaf area index were $(2.525$, 4.295 and 3.777) which were statistically similar with treatment $I_{3}$ and the lowest leaf area index were (1.292, 2.505 and 2.270).

Table 7 Effect of polythene mulching on leaf area index (LAl) of white maize

\begin{tabular}{lllll}
\hline Treatments & \multicolumn{4}{l}{ Leaf area index (LAI) } \\
& 30DAS & 60DAS & 90DAS & $\begin{array}{l}\text { At } \\
\text { Harvest }\end{array}$ \\
\hline $\mathrm{P}_{0}$ & $0.58 \mathrm{~b}$ & $1.68 \mathrm{~b}$ & $3.094 \mathrm{~b}$ & $2.727 \mathrm{~b}$ \\
$\mathrm{P}$ & $0.82 \mathrm{a}$ & $2.09 \mathrm{a}$ & $4.023 \mathrm{a}$ & $3.665 \mathrm{a}$ \\
\hline LSD $(0.05)$ & 0.14 & 0.05 & 0.165 & 0.05 \\
$\mathrm{CV} \%$ & $11.5 \mathrm{I}$ & 1.78 & 2.89 & 1.41
\end{tabular}

Interaction of polythene mulching and irrigation frequency showed significant variation with advances of growth period in respect of leaf area index except at 30 DAS (Figure 6). At 30 DAS, the maximum leaf area index (0.94) was observed in $\mathrm{PI}_{4}$ and the lowest leaf area index was observed in $\mathrm{P}_{0} \mathrm{I}_{0}$. At 60, 90DAS and harvest stage, the maximum leaf area index $(2.933,4.817$ and 4.413$)$ was observed in $\mathrm{PI}_{4}$ which was statistically similar with $\mathrm{PI}_{3}$ and the minimum leaf area index $\left(1.30,2.243\right.$ and 2.047) was observed in $\mathrm{P}_{0} \mathrm{I}_{0}$ which was statistically similar with $\mathrm{P}_{0} \mathrm{I}_{1}, \mathrm{PI}_{0}$ and $\mathrm{PI}_{1}$ at $60 \mathrm{DAS}$. Kalaghatagi et $a l .^{20}$ also reported that irrigation with black polythene mulch spread between the rows significantly increased the dry matter at harvest, leaf area at 60 days after sowing in maize.

Table 8 Effect of irrigation frequency on leaf area index (LAl) of white maize

\begin{tabular}{lllll}
\hline \multirow{2}{*}{ Treatments } & \multicolumn{4}{l}{ Leaf area index (LAI) } \\
& 30 DAS & 60DAS & 90DAS & $\begin{array}{l}\text { At } \\
\text { Harvest }\end{array}$ \\
\hline $\mathrm{I}_{0}$ & 0.57 & $1.292 \mathrm{c}$ & $2.505 \mathrm{~d}$ & $2.270 \mathrm{~d}$ \\
$\mathrm{I}_{1}$ & $0.6 \mathrm{I}$ & $1.375 \mathrm{c}$ & $3.213 \mathrm{c}$ & $3.000 \mathrm{c}$ \\
$\mathrm{I}_{2}$ & 0.72 & $1.750 \mathrm{~b}$ & $3.517 \mathrm{~b}$ & $3.223 \mathrm{~b}$ \\
$\mathrm{I}_{3}$ & 0.79 & $2.477 \mathrm{a}$ & $4.263 \mathrm{a}$ & $3.710 \mathrm{a}$ \\
$\mathrm{I}_{4}$ & $0.8 \mathrm{I}$ & $2.525 \mathrm{a}$ & $4.295 \mathrm{a}$ & $3.777 \mathrm{a}$ \\
\hline LSD (0.05) & $\mathrm{NS}$ & 0.14 & 0.194 & 0.145 \\
CV\% & 15.69 & 6.2 & 4.47 & 3.74 \\
\hline
\end{tabular}

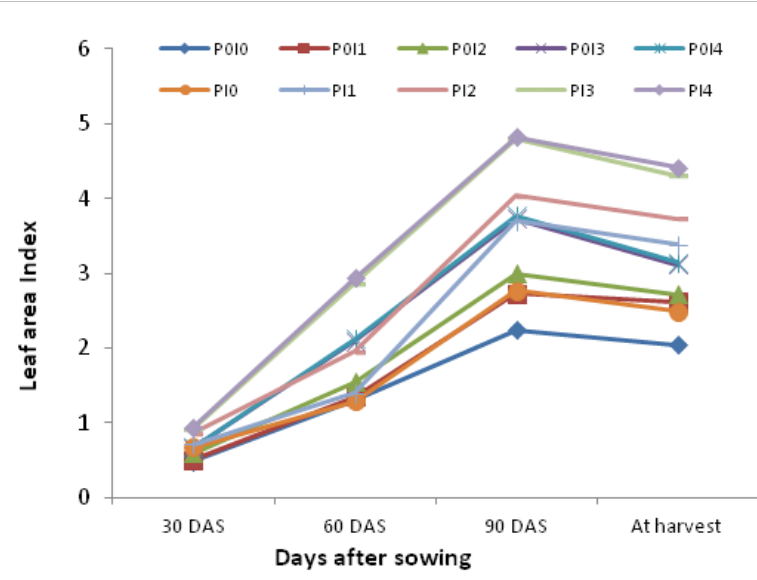

Figure 6 Interaction effect of polythene mulching and irrigation frequency on leaf area index of white maize

Significant variation was recorded for cob length of maize due to application of polythene mulch in (Table 9). The longest cob was recorded $(24.58 \mathrm{~cm})$ in $\mathrm{P}$ (polythene mulching) and was noted minimum $(21.03 \mathrm{~cm})$ was found in control treatment. This is similar to the findings of Pinjari ${ }^{23}$ who reported that the polythene mulch on sweet corn increased the cob length.

Table 9 Effect of polythene mulching on yield contributing characters of white maize

\begin{tabular}{lllll}
\hline Treatments & $\begin{array}{l}\text { Cob } \\
\text { length }\end{array}$ & $\begin{array}{l}\text { Cob } \\
\text { circumference }\end{array}$ & Rows/cob & Seeds/row \\
\hline $\mathrm{P}_{0}$ & $21.03 \mathrm{~b}$ & $15.96 \mathrm{~b}$ & $12.73 \mathrm{~b}$ & $23.17 \mathrm{~b}$ \\
$\mathrm{P}_{1}$ & $24.58 \mathrm{a}$ & $17.37 \mathrm{a}$ & $13.68 \mathrm{a}$ & $27.10 \mathrm{a}$ \\
\hline LSD (0.05) & 1.24 & 0.14 & 0.186 & 1.324 \\
$\mathrm{CV}(\%)$ & 3.46 & 3.55 & 1.89 & 3.35 \\
\hline
\end{tabular}

Cob length of maize was significantly different due to the irrigation frequencies (Table 10). Cob length of maize ranged from 26.52 to 19.59 $\mathrm{cm}$, longest cob was found in $\mathrm{I}_{4}$ treatment which is not statistically similar to others treatments. The lowest cob length $19.59 \mathrm{~cm}$ was recorded treatment $\mathrm{I}_{0}$. The treatment $\mathrm{I}_{4}$ was statistically superior to $\mathrm{I}_{0}$ $I_{1}, I_{3}$ treatments in terms of cob length. The grain yield of maize was positively correlated with cob length characters. The results obtained 
from the present study were similar to the findings of Mohapatra et al. ${ }^{24}$ They said soil moisture increase cob length.

Table 10 Effect of irrigation frequency on yield contributing characters of white maize

\begin{tabular}{lllll}
\hline Treatments & $\begin{array}{l}\text { Cob } \\
\text { length } \\
(\mathrm{cm})\end{array}$ & $\begin{array}{l}\text { Cob } \\
\text { circumference } \\
(\mathrm{cm})\end{array}$ & Rows/cob & $\begin{array}{l}\text { Seeds/ } \\
\text { row }\end{array}$ \\
\hline $\mathrm{I}_{0}$ & $19.59 \mathrm{e}$ & $13.22 \mathrm{~d}$ & $11.30 \mathrm{~d}$ & $16.50 \mathrm{~d}$ \\
$\mathrm{I}_{1}$ & $21.14 \mathrm{~d}$ & $15.57 \mathrm{c}$ & $12.5 \mathrm{I} \mathrm{c}$ & $21.58 \mathrm{c}$ \\
$\mathrm{I}_{2}$ & $22.11 \mathrm{c}$ & $16.80 \mathrm{~b}$ & $12.87 \mathrm{~b}$ & $25.33 \mathrm{~b}$ \\
$\mathrm{I}_{3}$ & $24.66 \mathrm{~b}$ & $18.84 \mathrm{a}$ & $14.61 \mathrm{a}$ & $30.97 \mathrm{a}$ \\
$\mathrm{I}_{4}$ & $26.52 \mathrm{a}$ & $18.89 \mathrm{a}$ & $14.73 \mathrm{a}$ & $31.28 \mathrm{a}$ \\
\hline $\mathrm{LSD} 0.05$ & 0.58 & 0.27 & 0.17 & 1.67 \\
CV $(\%)$ & 2.06 & 1.3 & 1.08 & 5.43 \\
\hline
\end{tabular}

From the value of cob length it was found that interaction effect of polythene mulching and irrigation frequency showed significant differences (Figure 7). The highest cob length $(27.63 \mathrm{~cm})$ was observed for the combination of $\mathrm{PI}_{4}$ treatment which was statistically similar with $\mathrm{PI}_{3}$. The lowest cob length $(18.72 \mathrm{~cm})$ was observed in $\mathrm{P}_{0} \mathrm{I}_{0}$ treatment combination which was statistically similar with $\mathrm{P}_{0} \mathrm{I}_{1}$ treatment The results obtained from the present study were similar to those of Mohapatra et al. ${ }^{24}$

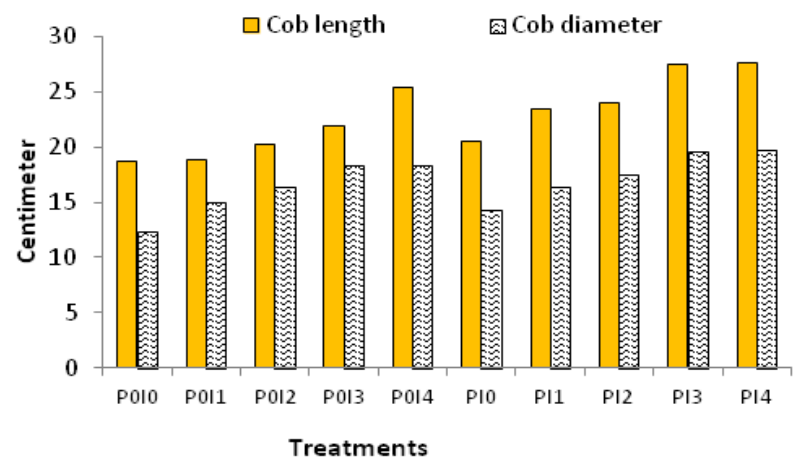

Figure 7 Interaction effect of polythene mulching and irrigation frequency on cob length and cob circumference of white maize

Significant variations in cob circumference was observed by the application of polythene mulching (Table 9). Results showed that the highest cob circumference $(17.37 \mathrm{~cm})$ was obtained from treatment $\mathrm{P}$ (polythene mulch). The lowest cob circumference (15.96) was observed with $\mathrm{P}_{0}$ (control). The results are in line with the findings of Pinjari ${ }^{23}$ who reported that application of polythene mulch on sweet corn produced significantly higher cob circumference which ultimately increased the grain yields.

Maize polythene mulch exhibited significant difference in respect of the number of row $\mathrm{cob}^{-1}$ (Table 9). Among the treatments, $\mathrm{P}$ (polythene mulch) showed the maximum no. of row $\operatorname{cob}^{-1}$ (13.68) and no mulch $\left(\mathrm{P}_{0}\right)$ showed the minimum no. of row cob ${ }_{-1}$ (12.73). Quayyum and Ahmed ${ }^{25}$ stated that the highest number of rows per cob was found by using rice straw mulching that enhanced conservation of soil moisture and polythene mulch also conserve soil moisture and increase the number of grain rows per cob.
Maize variety exhibited significant difference in respect of the no. of grain row ${ }^{-1}$ (Table 9) in response of polythene mulching. Among the treatment and control, polythene mulching showed the maximum no. of grain row $^{-1}(27.10)$ and $\mathrm{P}_{0}$ (control) showed the minimum no. of grain row $^{-1}$ (23.17). Mohapatra et al. ${ }^{23}$ concluded that polythene mulching increased the intensity of cobbing, probably the increased available soil moisture as a result of mulching helped in increasing the cobs/plant, cob length, cob circumference, weight/cob, rows of grains/cob, grains/cob and grain yield/ha.

Cob circumference was significantly influenced by different irrigation frequency (Table 10). Results showed that the highest effective cob circumference $(18.89 \mathrm{~cm})$ was $\mathrm{I}_{4}$ which was statistically similar with $\mathrm{I}_{3}$ and the lowest cob circumference $(13.22 \mathrm{~cm})$ with $\mathrm{I}_{0}$ treatment. This result is in agreement with Mohapatra et al. ${ }^{24}$

The irrigation frequency exerted a significant variation in respect of the no. of row $\mathrm{cob}^{-1}$ (Table 10). Irrigation frequency $\left(\mathrm{I}_{4}\right)$ showed the maximum no. of row $\mathrm{cob}^{-1}$ (14.73) which was statistically similar with treatment $\mathrm{I}_{3}$ (14.61); whereas $\mathrm{I}_{0}$ showed the minimum no. of row cob1 (11.30) which was statistically different from others. This is similar to the findings of Panda et al..$^{26}$ who reported that the effect of different irrigation scheduling methods had effect on root zone soil moisture, growth, yield parameters and water use efficiency of corn.

Irrigation frequency showed a significant variation in respect of the no. of grain row ${ }^{-1}$ (Table 10). Irrigation frequency $\left(\mathrm{I}_{4}\right)$ showed the maximum no. of grain row $^{-1}(31.28)$ which was statistically similar with $\mathrm{I}_{3}$; whereas Irrigation frequency $\left(\mathrm{I}_{0}\right)$ showed the minimum no. of grain row $^{-1}(16.50)$ which was statistically different from others.

Cob circumference was significantly influenced by interaction effect of polythene mulching and irrigation frequency (Figure 7). Results showed that highest cob circumference $(19.55 \mathrm{~cm})$ was found with the treatment combination of $\mathrm{PI}_{4}$ although this was at par with $\mathrm{PI}_{3}$ in this respect. On the other hand the lowest cob circumference was observed with $\mathrm{P}_{0} \mathrm{I}_{0}(12.23 \mathrm{~cm})$. The results obtained from the present study were in conformity with the findings of Mohapatra et al..$^{24}$ They found that mulching following the irrigation confirmed 50 per cent available soil moisture which eventually increased the cob length.

Interaction of polythene mulching and irrigation frequency showed significant variation in respect of the no. of row $\mathrm{cob}^{-1}$ (Figure 8). The maximum no. of row $\mathrm{cob}^{-1}$ (15.43) was observed in $\mathrm{PI}_{4}$ which was statistically similar with $\mathrm{PI}_{3}$; whereas the minimum no. of row $\mathrm{cob}^{-1}$ (10.9) was observed in $\mathrm{P}_{0} \mathrm{I}_{0}$ which was lowest in comparison to other combinations. Mohapatra et al. ${ }^{24}$ found that mulching with irrigation confirmed $50 \%$ available soil moisture which in turn increased the rows of grains/cob as well as grain yield over all.

Interaction effect of polythene mulching and irrigation frequency showed significant variation in respect of the no. of grain row ${ }^{-1}$ (Figure 9). The maximum no. of grain row $^{-1}$ (34.55) was observed in $\mathrm{PI}_{4}$ which was statistically similar with $\mathrm{PI}_{3}$; whereas the minimum number of grain row ${ }^{-1}$ (15.50) was observed in $\mathrm{P}_{0} \mathrm{I}_{0}$ which was statistically similar with $\mathrm{P}_{1} \mathrm{I}_{0}$.

Number of grains $\mathrm{cob}^{-1}$ was significantly influenced by application of polythene mulching in the present study (Table 11). Results showed that the highest number of grains $\operatorname{cob}^{-1}(412.40)$ was recorded with $P$ which was statistically dissimilar with $\mathrm{P}_{0}$ and the lowest number of grains $\mathrm{cob}^{-1}(373.10)$ with treatment. Pinjari ${ }^{23}$ found the similar result that number of grains per cob increased under polythene mulch over no mulch. 
Statistically significant variations in grain weight $\mathrm{cob}^{-1}$ was observed due to mulching with polythene (Table 11). The maximum grain weight per cob (102.10g) was found at P treatment and the weight of grain per cob $(75.08 \mathrm{~g})$ at $\mathrm{P}_{0}$ treatment. Pinjari ${ }^{23}$ found the effect of polythene mulch in sweet corn revealing that the different yield attributes viz. weight of grains per cob and weight per cob were significantly superior under polythene mulch over no mulch.

Table II Effect of polythene mulching on yield contributing characters of white maize

\begin{tabular}{llll}
\hline Treatments & $\begin{array}{l}\text { No. of grain/ } \\
\text { cob }\end{array}$ & $\begin{array}{l}\text { Grain weight/ } \\
\text { cob }\end{array}$ & $\begin{array}{l}\text { I00 Grain } \\
\text { weight }(\mathrm{g})\end{array}$ \\
\hline $\mathrm{P}_{0}$ & $373.10 \mathrm{~b}$ & $75.08 \mathrm{~b}$ & 29.95 \\
$\mathrm{P}_{1}$ & $412.40 \mathrm{a}$ & $102.10 \mathrm{a}$ & 33.88 \\
\hline LSD (0.05) & 25.65 & 4.60 & $\mathrm{NS}$ \\
$\mathrm{CV}(\%)$ & 4.16 & 3.30 & 9.04 \\
\hline
\end{tabular}

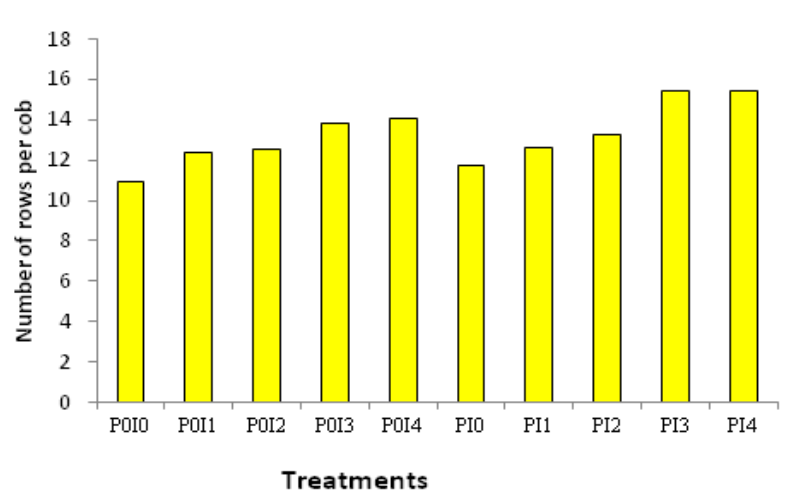

Figure 8 Interaction effect of polythene mulching and irrigation frequency on no. of rows per cob of white maize

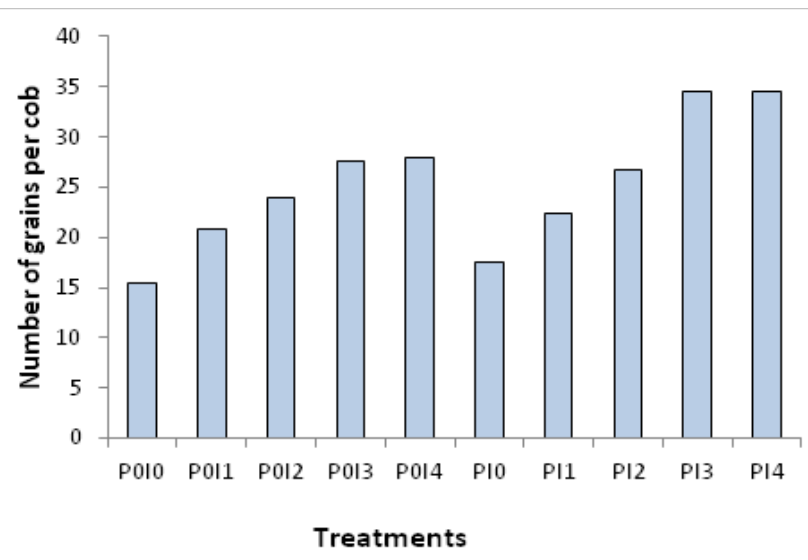

Figure 9 Interaction effect of polythene mulching and irrigation frequency on no. of grains per row of white maize

No significant variations in number of 100 -grain weight was observed due to the application of polythene mulching in (Table 11). The treatment P produced the highest 100 -grain weight of $33.88 \mathrm{~g}$ and the treatment $\mathrm{P}_{0}$ showed the lowest 100 -grain weight of $29.95 \mathrm{~g}$. The 100 seeds weight and grain yield of maize was affected due to moisture conservation properties soil. This result is agreed with Kulkarni et al. ${ }^{22}$ who reported that mulching increased soil moisture content and the increased availability of soil moisture probably helped to increase the 1000 grain weight of maize.

Significant variation was observed on number of grains $\mathrm{cob}^{-1}$ in case of different frequency of irrigation (Table 12). The highest number of grains $\mathrm{cob}^{-1}$ was observed at $\mathrm{I}_{4}$ treatment (467.40) which was not statistically different with $\mathrm{I}_{3}$ The lowest number of grains $\mathrm{cob}^{-1}$ was observed at $\mathrm{I}_{0}$ treatment (308.20) which was at par with $\mathrm{I}_{1}$. Pandey et al. ${ }^{20}$ stated that applying drought stress at various growth stages of corn generally reduced seed yield, number of seeds/cob. The result was similar to the present study.

The effect of irrigation frequency had significant effect on weight of grain $\mathrm{cob}^{-1}$ (Table 12). The highest grain weight $\mathrm{cob}^{-1}$ was observed for the treatment combination of $\mathrm{I}_{4}(121.7 \mathrm{~g})$ which was statistically similar with treatment $\mathrm{I}_{3}(118.5 \mathrm{~g})$ and the lowest grain weight $\mathrm{cob}^{-1}$ $(54.1 \mathrm{~g})$ observed in $\mathrm{I}_{0}$ treatment. Pandey et al. ${ }^{20}$ reported that applying drought stress at various growth stages of corn generally reduced seed yield, number of seeds/cob, 1000-seed weight as well as grain weight per cob. This study emphases that irrigation scheduling is very effective at various growth stage of maize for increasing the grain weight in a cob.

Significant variation was recorded in weight of 100 -grain of maize due to different irrigation frequency (Table 12). The treatment $\mathrm{I}_{4}$ produced significantly the highest 100 grain weight of $33.90 \mathrm{~g}$ which was similar with $\mathrm{I}_{3}$ while $\mathrm{I}_{0}$ produced significantly the lowest 100 -grain weight of $29.68 \mathrm{~g}$ which was at par with $\mathrm{I}_{1}$ and $\mathrm{I}_{2}(30.59$ and $31.55 \mathrm{~g})$. Pandey et al. ${ }^{20}$ reported that applying drought stress at various growth stages of corn generally reduced seed yield and 1000-seed weight. This happened due to the continued supply of soil moisture which increased the 1000-seed weight as well as seed yield.

Table 12 Effect of irrigation frequency on yield contributing characters of white maize

\begin{tabular}{llll}
\hline Treatments & $\begin{array}{l}\text { No. of } \\
\text { grain/cob }\end{array}$ & $\begin{array}{l}\text { Grain weight/ } \\
\text { cob }\end{array}$ & $\begin{array}{l}\text { I00 Grain } \\
\text { weight }(\mathrm{g})\end{array}$ \\
\hline $\mathrm{I}_{0}$ & $308.20 \mathrm{c}$ & $54.10 \mathrm{~d}$ & $29.68 \mathrm{~b}$ \\
$\mathrm{I}_{1}$ & $332.90 \mathrm{c}$ & $1,463.43 \mathrm{c}$ & $30.59 \mathrm{~b}$ \\
$\mathrm{I}_{2}$ & $393.20 \mathrm{~b}$ & $85.27 \mathrm{~b}$ & $31.55 \mathrm{~b}$ \\
$\mathrm{I}_{3}$ & $462.00 \mathrm{a}$ & $118.50 \mathrm{a}$ & $33.83 \mathrm{a}$ \\
$\mathrm{I}_{4}$ & $467.40 \mathrm{a}$ & $121.70 \mathrm{a}$ & $33.90 \mathrm{a}$ \\
\hline LSD (0.05) & 25.7 & 5.54 & 2.27 \\
CV (\%) & 5.35 & 5.11 & 5.82 \\
\hline
\end{tabular}

Number of grains $\mathrm{cob}^{-1}$ was significantly influenced by interaction effect of polythene mulching and irrigation frequency (Figure 10). Results showed that the highest number of grains $\mathrm{cob}^{-1}(510.10)$ was found with the treatment combination of $\mathrm{PI}_{4}$ which was however similar with that of $\mathrm{PI}_{3}(500.30)$. On the other hand the lowest number of grains $\mathrm{cob}^{-1}(306.0)$ was observed with $\mathrm{P}_{0} \mathrm{I}_{0}$ which was again statistically similar with $\mathrm{P}_{0} \mathrm{I}_{1} \mathrm{PI}_{0} \mathrm{PI}_{1}$ Mohapatra et al..$^{24}$ stated that the number of grains per cob depended on the available soil moisture in the soil which was increased by mulching with irrigation.

The grain weight $\mathrm{cob}^{-1}$ was also shown significantly variation due to interaction effect of the treatments (Figure 11). The grain weight $\mathrm{cob}^{-1}$ of maize ranged from 48.20 to $140.6 \mathrm{~g}$. The highest grain weight cob ${ }^{1}$ was found in $\mathrm{PI}_{4}(140.6 \mathrm{~g})$ which was statistically similar with $\mathrm{PI}_{3}$ $(138 \mathrm{~g})$. The lowest grain weight $\mathrm{cob}^{-1}$ was recorded with $\mathrm{P}_{0} \mathrm{I}_{0}$ treatment (48.2g) which was statistically similar with $\mathrm{P}_{0} \mathrm{I}_{1}(50.2 \mathrm{~g})$. Mohapatra et al. ${ }^{24}$ concluded that mulching with irrigation helped to save $50 \%$ 
available soil moisture which in turn increased the grain weight per cob as well as grain yield of maize.

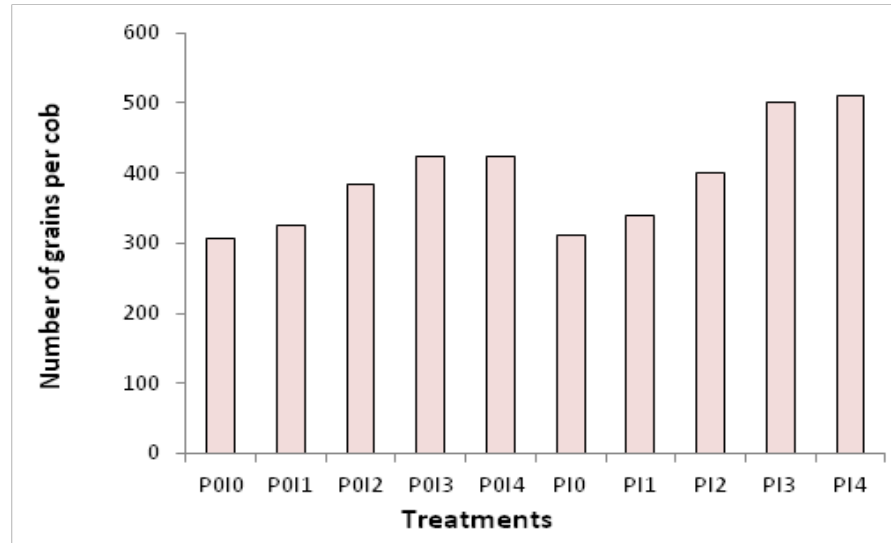

Figure 10 Interaction effect of polythene mulching and irrigation frequency on no. of grain per cob of white maize

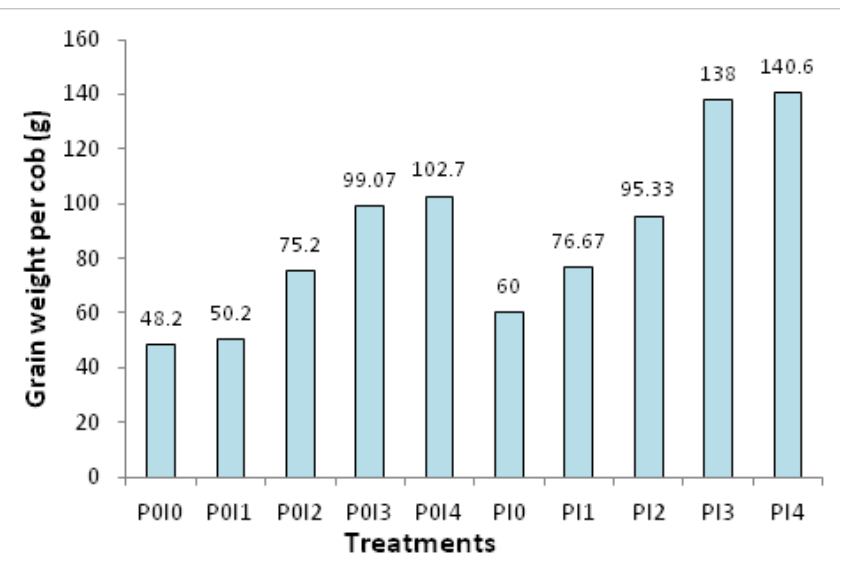

Figure I I Interaction effect of polythene mulching and irrigation frequency on grain weight per cob of white maize

Interaction effect of polythene mulching and irrigation frequency was significant on weight of 100-grain weight of maize (Figure 12). The highest weight of 100 grain $\left(36.33 \mathrm{~g}\right.$ ) was observed from $\mathrm{PI}_{4}$ which was statistically similar with $\mathrm{PI}_{3}$. The 100 -seed weight from $\mathrm{PI}_{3}$ was not significantly higher than those of $\mathrm{PI}_{2}$ and $\mathrm{PI}_{0}$ treatments. While the lowest 100-grain weight $(26.51 \mathrm{~g})$ was recorded from $\mathrm{P}_{0} \mathrm{I}_{0}$. It appeared that the mulching with irrigation increased the availability of soil moisture which increased the values of yield components and consequently that of yield in maize. Kalaghatagi et al. ${ }^{21}$ reported that irrigation with black polythene mulch spread between the rows significantly increased the number of grains/cob, grain weight/cob, 1000 grain weight of maize.

Grain yield was significantly influenced by application of polythene mulching used in the present study (Table 13). Results showed that the highest grain yield $\left(9.40 \mathrm{t} \mathrm{ha}^{-1}\right)$ was found in P. On the other hand the lowest grain yield $\left(6.97 \mathrm{t} \mathrm{ha}^{-1}\right.$. Probably the grain yield of wheat was affected by changes in soil moisture conservation due to mulching with polythene sheet. From this study it appears that polythene mulching increased soil moisture percentage and also the availability of nutrients which eventually increased the values of yield components as well as that of yield of maize. Liu et al. ${ }^{27}$ reported that the transplanting spring maize with plastic film mulching improved the ecological environment of the soil, increased soil temperature and soil water contents, promoted the growth and maturation of maize and increased crop yield. Kwabiah ${ }^{28}$ found that the plastic mulch increased the total cob yield by $8-17 \%$ over no mulch. Plastic mulching increased grain yield from 2 to $4 \mathrm{tha}^{-1}$ in maize as was reported by Easson $^{28}$. In another work it was observed that the black polythene mulch increased grain yield by up to $146 \%$ in maize ${ }^{29}$. Similar result was also found by Shelley ${ }^{29}$ in maize who observed that among the polythene mulches, black polythene showed the highest yield.

Table I 3 Effect of polythene mulching on yield parameters of white maize

\begin{tabular}{lllll}
\hline Treatments & $\begin{array}{l}\text { Grain yield } \\
(\mathrm{t} / \mathrm{ha})\end{array}$ & $\begin{array}{l}\text { Straw yield } \\
(\mathrm{t} / \mathrm{ha})\end{array}$ & $\begin{array}{l}\text { Biological } \\
\text { yield (t/ha) }\end{array}$ & $\begin{array}{l}\text { Harvest } \\
\text { Index }(\%)\end{array}$ \\
\hline $\mathrm{P}_{0}$ & $6.97 \mathrm{~b}$ & $10.93 \mathrm{~b}$ & $17.90 \mathrm{~b}$ & 38.88 \\
$\mathrm{P}$ & $9.40 \mathrm{a}$ & $13.90 \mathrm{a}$ & $23.30 \mathrm{a}$ & 39.76 \\
\hline LSD (0.05) & 0.4 & 0.35 & 0.57 & 0.81 \\
$\mathrm{CV}(\%)$ & 3.09 & 1.81 & 1.76 & 1.74 \\
\hline
\end{tabular}

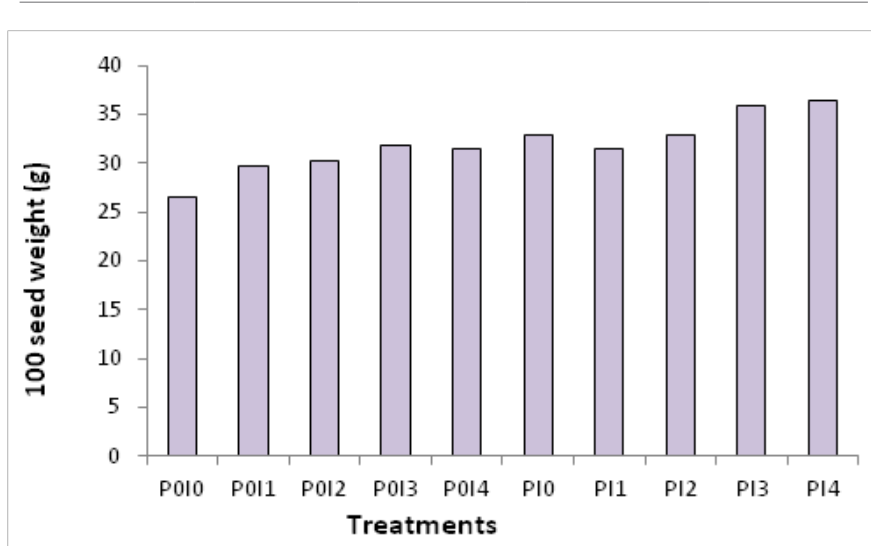

Figure 12 Interaction effect of polythene mulching and irrigation frequency on 100-grain weight of white maize

Straw yield of maize showed statistically significant variation due to mulching with polythene sheet (Table 13). The highest straw yield of $13.90 \mathrm{t} \mathrm{ha}^{-1}$ was recorded from $\mathrm{P}$ treatment. On the other hand, the lowest straw yield $10.93 \mathrm{t} \mathrm{ha}^{-1}$ was observed from $\mathrm{P}_{0}$ treatment. The application of mulching increased soil moisture helping to increase the grain and straw yield. Gosavi ${ }^{30}$ also reported that significantly highest green cob and stover yield under polythene mulch than control.

It was revealed from the experiment that biological yield of maize showed significant variation due to application of polythene mulching (Table 13).The highest biological yield (23.17 $\left.\mathrm{t} \mathrm{ha}^{-1}\right)$ was observed from $\mathrm{P}$ treatment. On the other hand, the lowest biological yield $\left(17.90 \mathrm{t} \mathrm{ha}^{-1}\right)$ was observed from $\mathrm{P}_{0}$ treatment. The results obtained from the present study is in consistent with the findings of Kwabiah ${ }^{28}$ who reported that the plastic mulch increased the total biomass yield by $3-6 \%$ over that of no mulch.

Harvest index of maize showed statistically significant variation due to application of polythene mulching (Table 13). Numerically, the highest harvest index (39.76\%) was recorded from $P$ treatment and the lowest harvest index $(38.88 \%)$ was obtained from $\mathrm{P}_{0}$ treatment. In polythene applied plots (P), soil moisture was conserved which helped translocation of photosynthate towards the grain formation increasing the dry matter of the grain which ultimately increased the HI of maize. On contrary, the plots having no polythene mulch 
were lost soil moisture which intern may have caused water shortage in plant's body and may have resulted in reduced photosynthate translocation upwards decreasing the $\mathrm{HI}$ value. Gosavi ${ }^{30}$ reported that significantly highest green cob and stover yield were recorded under polythene mulch than control and harvest index of crop fully depended on grain yield and biological yield of crop.

Significant variation was observed on grain yield in case of frequent irrigation in the field (Table 14). It was found that the highest grain yield $\left(10.61 \mathrm{t} \mathrm{ha}^{-1}\right)$ was achieved from $\mathrm{I}_{4}$ and it was statistically similar with $\mathrm{I}_{3}$ treatment showing the grain yield of $10.54 \mathrm{t} \mathrm{ha}^{-1}$. On the other hand, the lowest grain yield (5.00 $\mathrm{t} \mathrm{ha}^{-1}$ ) was found in $\mathrm{I}_{0}$ (control). The results obtained from all other treatments gave intermediate results. Panda et al. ${ }^{26}$ evaluated the effect of different irrigation scheduling methods and reported improvement in root zone soil moisture, growth, yield parameters and water use efficiency of corn. They concluded that under water scarcity conditions, irrigation should be scheduled at $45 \%$ of the maximum allowable depletion of available soil water of corn to obtain high yield parameters.

Straw yield of maize showed statistically significant variation due to different levels of irrigations (Table 14). The highest straw yield of $15.13 \mathrm{t} \mathrm{ha}^{-1}$ was recorded from $\mathrm{I}_{4}$ treatment which was statistically similar with $\mathrm{I}_{3}$ treatment. On the other hand, the lowest straw yield $8.583 \mathrm{t} \mathrm{ha}^{-1}$ was observed from $\mathrm{I}_{0}$ treatment.

Table I4 Effect of irrigation frequency on yield parameters of white maize

\begin{tabular}{lllll}
\hline Treatments & $\begin{array}{l}\text { Grain } \\
\text { yield(t/ha) }\end{array}$ & $\begin{array}{l}\text { Straw yield } \\
(\mathrm{t} / \mathrm{ha})\end{array}$ & $\begin{array}{l}\text { Biological } \\
\text { yield(t/ha) }\end{array}$ & $\begin{array}{l}\text { Harvest } \\
\text { Index(\%) }\end{array}$ \\
\hline $\mathrm{I}_{0}$ & $5.000 \mathrm{~d}$ & $8.58 \mathrm{~d}$ & $13.58 \mathrm{~d}$ & $36.93 \mathrm{c}$ \\
$\mathrm{I}_{1}$ & $6.885 \mathrm{c}$ & $11.15 \mathrm{c}$ & $18.03 \mathrm{c}$ & $38.25 \mathrm{bc}$ \\
$\mathrm{I}_{2}$ & $7.892 \mathrm{~b}$ & $12.14 \mathrm{~b}$ & $20.03 \mathrm{~b}$ & $39.46 \mathrm{ab}$ \\
$\mathrm{I}_{3}$ & $10.540 \mathrm{a}$ & $15.06 \mathrm{a}$ & $25.60 \mathrm{a}$ & $40.97 \mathrm{a}$ \\
$\mathrm{I}_{4}$ & $10.610 \mathrm{a}$ & $15.13 \mathrm{a}$ & $25.75 \mathrm{a}$ & $40.98 \mathrm{a}$ \\
\hline $\operatorname{LSD}(0.05)$ & 0.280 & 0.9 & 0.96 & 2.13 \\
$\mathrm{CV}(\%)$ & 2.76 & 5.9 & 3.82 & 4.42 \\
\hline
\end{tabular}

Grain yield was significantly influenced by interaction effect of polythene mulching and irrigation frequency (Figure 13). Results showed that the highest grain yield $\left(12.810 \mathrm{t} \mathrm{ha}^{-1}\right)$ was found with the treatment combination of $\mathrm{PI}_{4}$ which was statistically similar with $\mathrm{PI}_{3}$. On the other hand the lowest grain yield $\left(4.77 \mathrm{t} \mathrm{ha}^{-1}\right)$ was observed with $\mathrm{P}_{0} \mathrm{I}_{0}$.

$\mathrm{PI}_{2}, \mathrm{P}_{0} \mathrm{I}_{3}$ and $\mathrm{P}_{0} \mathrm{I}_{4}$ treatments gave statistically similar yield. Mohapatra et al. ${ }^{24}$ and Kalaghatagi et al. ${ }^{21}$ also found the similar finding relation to grain yield which was increased due to soil moisture availability as a result of polythene mulching. Hundred seed weight (Figure 14) was the highest with PI4 (42.60 g) and the lowest with PI0 (36.49 g).

Interaction effect of polythene mulching and irrigation frequency showed significant differences on straw yield of maize (Figure 13). The highest straw yield $\left(17.27 \mathrm{t} \mathrm{ha}^{-1}\right)$ was observed from $\mathrm{PI}_{4}$ which was at par with $\mathrm{PI}_{3}$, while the lowest straw yield $\left(8.00 \mathrm{t} \mathrm{ha}^{-1}\right)$ was obtained from $\mathrm{P}_{0} \mathrm{I}_{0}$ which was again at par with $\mathrm{PI}_{0}$ treatment. The results obtained from the present study were in conformity with the findings of Kalaghatagi et al. ${ }^{21}$ who reported that irrigation followed by polythene mulching significantly increased the fodder yield.
Statistically significant variation was observed in biological yield of maize due to irrigations frequencies (Figure 13). The highest biological yield $\left(25.75 \mathrm{t} \mathrm{ha}^{-1}\right)$ was observed from $\mathrm{I}_{4}$ treatment which was statistically similar with $\mathrm{I}_{3}$ treatment $\left(25.60 \mathrm{t} \mathrm{ha}^{-1}\right)$ while the lowest biological yield (13.58 $\mathrm{tha}^{-1}$ ) was recorded from $\mathrm{I}_{0}$ treatment. The results obtained from the present study were in agreement with the findings of Panda et al. ${ }^{26}$ who evaluated the effect of different irrigation scheduling methods on root zone soil moisture, growth, yield parameters and water use efficiency of corn which is related to grain and straw yield.

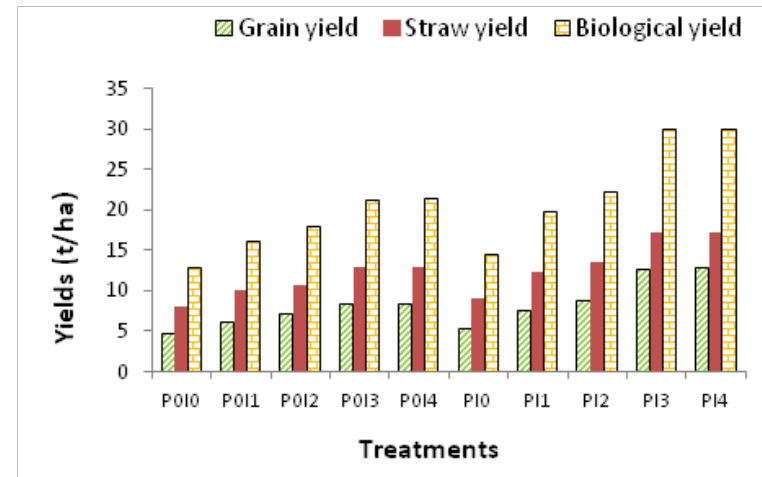

Figure 13 Interaction effect of polythene mulching and irrigation frequency on grain yield, straw yield, biological yield and harvest index of white maize

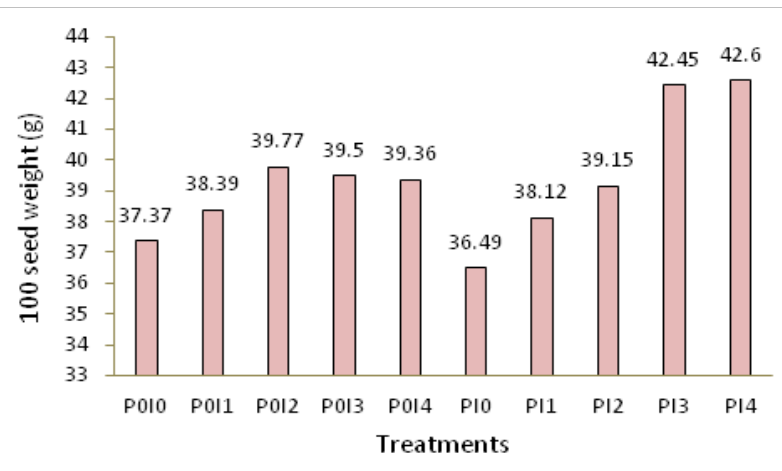

Figure 14 Interaction effect of polythene mulching and irrigation on the 100 seed weight of white maize

Interaction effect of polythene mulching and irrigation frequency showed significant differences on biological yield of maize (Figure 13). The highest biological yield $\left(30.08 \mathrm{tha}^{-1}\right)$ was observed from $\mathrm{PI}_{4}$ treatment which was statistically similar with $\mathrm{PI}_{3}\left(29.97 \mathrm{tha}^{-1}\right)$ and the lowest biological yield $\left(12.77 \mathrm{tha}^{-1}\right)$ was recorded from $\mathrm{P}_{0} \mathrm{I}_{0}$ treatment.

Data revealed that there was significant variation for harvest index of maize due to different irrigation frequency (Figure 13). Numerically, the highest harvest index $(40.98 \%)$ was observed from $\mathrm{I}_{4}$ treatment which was statistically similar with $\mathrm{I}_{3}$ and $\mathrm{I}_{2}$ treatments and the lowest $36.93 \%$ was from $\mathrm{I}_{0}$ treatment which was statistically similar with $\mathrm{I}_{1}$ treatment.

Interaction effect of polythene mulching and irrigation frequency showed significant differences on harvest index of maize (Figure 13). The highest harvest index $(42.60 \%)$ was observed from $\mathrm{PI}_{4}$ treatment which was statistically similar with $\mathrm{PI}_{3}$ and $\mathrm{P}_{0} \mathrm{I}_{2}$, while the lowest harvest index (36.49\%) was recorded from $\mathrm{P}_{1} \mathrm{I}_{0}$ which was statistically similar with $\mathrm{P}_{0} \mathrm{I}_{0}, \mathrm{P}_{0} \mathrm{I}_{1}, \mathrm{P}_{0} \mathrm{I}_{3}, \mathrm{P}_{0} \mathrm{I}_{4}, \mathrm{PI}_{1}$ and $\mathrm{PI}_{2}$ treatments. Harvest index of crop fully depends on grain yield and biological yield of crop. 
Grain yield and fodder yield increased with the polythene mulching with irrigation stated by Kalaghatagi et al. ${ }^{21}$

Recommendation: In a maize crop, generally four or more irrigation is required for obtaining higher seed yield. In this study one irrigation could be saved through conserving soil moisture by covering the soil surface after irrigation with polythene. However, one study may not be enough to draw the final conclusion. So, this study may be repeated in different agro-climatic regions to optimize the irrigation frequencies under post irrigation polythene application.

\section{References}

1. Bangladesh Bureau of Statistics. Yearbook of Agricultural Statistics of Bangladesh-2016. Bangladesh Bureau of Statistics; 2017.

2. FAO, CIMMYT. White Maize: a Traditional Food Grain in Developing Countries. U N Food Agric Organziantion FAO Int Maize Wheat Improv Cent CIMMYT Rome Italy. 1997.

3. Food and Agricultural Organization of the United Nations (FAO). Structure and Characteristics of the World White Maize Economy. In: Rome, Italy; 1984.

4. The World Bank Group. Data: Bangladesh.

5. BARI. Krishi Projukti Hath Boi (Handbook of Agriculture). 2016.

6. Islam TMT, Kaul AK. Prospects of Maize in Bangladesh. Dhaka, Bangladesh: FAO/UNDP; 1986:1-59, 109.

7. Rhoads F, Bennett J. Maize. In: Irrigation of Agricultural Crops. American Society of Agronomy; :569-596.

8. Stone PJ, Wilson DR, Reid JB, Gillespie RN. Water deficit effects on sweet corn. I. Water use, radiation use efficiency, growth, and yield. Aust J Agric Res. 2001;52(1):103-113.

9. Jordan JE, White RH, Vietor DM, Hale TC, Thomas JC, Engelke MC. Effect of irrigation frequency on turf quality, shoot density, and root length density of five bentgrass cultivars. Crop Sci. 2003;43(1):282-287.

10. Wan S, Kang Y. Effect of drip irrigation frequency on radish (Raphanus sativus L.) growth and water use. Irrig Sci. 2006;24(3):161-174.

11. Kijne JW, Barker R, Molden DJ. Water Productivity in Agriculture: Limits and Opportunities for Improvement. Vol 1. Cabi; 2003.

12. Spears TD. Irrigating efficiently to feed the world in 2050. In: Proceedings of the 2003 Irrigation Association International Exposition and Technical Conference, The Irrigation Association, Falls Church, VA. ; 2003:411422.

13. Fereres E, Soriano MA. Deficit irrigation for reducing agricultural water use. J Exp Bot. 2006;58(2):147-159.

14. Smart JR, Bradford JM. Conservation Tillage Corn Production for a Semiarid, Subtropical Environment. Agron J. 1999;91(1):116-121.

15. Voutsa D, Grimanis A, Samara C. Trace elements in vegetables grown in an industrial area in relation to soil and air particulate matter. Environ Pollut. 1996;94(3):325-335.
16. Guo ZL, Gu S-L. Effect of film mulching methods on yield and economic efficiency of millet. Agric Res Arid Areas. 2000;18(2):33-39.

17. Katan J, Greenberger A, Alon H, Grinstein A. Solar heating by polyethylene mulching for the control of diseases caused by soil-borne pathogens. Phytopathology. 1976;66(5):683-688.

18. Musa U, Usman T. Leaf area determination for maize (Zea mays L.), okra (Abelmoschus esculentus L.) and cowpea (Vigna unguiculata L.) crops using linear measurements. J Biol Agric Healthc. 2016;6(4):103-111.

19. Duhr E, Dubas A. Effect of covering the soil with plastic film on the dynamics of plant development and yield of maize sown on different dates. Pr Kom Nauk Rol Kom Nauk Śnych. 1990;69:9-18.

20. Pandey RK, Maranville JW, Chetima MM. Deficit irrigation and nitrogen effects on maize in a Sahelian environment: II. Shoot growth, nitrogen uptake and water extraction. Agric Water Manag. 2000;46(1):15-27.

21. Kalaghatagi SB, Kulkarni GN, Prabhakar AS, Palled YB. Effect of mulch on the use of irrigation water and grain yield in maize. Karnataka J Agric Sci. 1990;3(3-4):183-188.

22. Kulkarni GN, Kalaghatagi SB, Mutanal SM. Effect of various mulches and scheduling of irrigation on growth and yield of summer maize. $J$ Maharashtra Agric Univ. 1998;13(2):223-224.

23. Pinjari S. Effect of integrated nutrient management and polythene mulch on the performance of sweet corn under lateratc soils of Konkan. PhD Thesis. Dr. Balasaheb Sawant Konkan Krish Vidyaeeth, Daoli and Dist. Ratnagiri, 2007.

24. Mohapatra BK, Lenka D, Naik D. Effect of plastic mulching on yield and water use efficiency in maize. Ann Agric Res. 1998;19:210-211.

25. Quayyum MA, Ahmed A. Effect of tillage and mulching methods on the growth and yield of maize [in Bangladesh]. Bangladesh J Agric Res. 1993.

26. Panda RK, Behera SK, Kashyap PS. Effective management of irrigation water for maize under stressed conditions. Agric Water Manag. 2004;66(3):181-203.

27. Liu J, Xu SA, Zhou GY, Lu HH. Effects of transplanting multi-cropping spring maize with plastic film mulching on the ecological effect, plant growth and grain yield. J Hubei Agri Coll. 2002;2:100.

28. Kwabiah AB. Growth and yield of sweet corn (Zea mays L.) cultivars in response to planting date and plastic mulch in a short-season environment. Sci Hortic. 2004;102(2):147-166.

29. Shelley I. Effect of synthetic mulches on the morpho-physiological adaptation of maize. MS Thesis. Bangladesh Agricultural University, 2002.

30. Gosavi A. Effect of mulches, fertilizer and levels of organic manure on the performance of rabi sweet corn (Zea mays saccharata). MS Thesis. Dr. Balasaheb Sawant Konkan Krishi Vidyapeeth, Dapoli, Dist. Ratnagiri, 2006. 